\title{
APLIKASI PENILAIAN JAWABAN ESAI OTOMATIS MENGGUNAKAN METODE SYNONYM RECOGNITION DAN COSINE SIMILARITY BERBASIS WEB
}

\author{
Imam Mufiid ${ }^{1}$, Sri Lestanti ${ }^{2}$, Ni’ma Kholila ${ }^{3}$ \\ 1,2,3 Teknik Informatika S1 Universitas Islam Balitar \\ imammufid98@gmail.com
}

\begin{abstract}
ABSTRAK
Ujian merupakan salah satu alat penilaian dalam proses belajar mengajar untuk menentukan kualitas pembelajaran. Namun disisi lain ujian merupakan suatu kesibukan tambahan yang harus dilakukan oleh pengajar terutama dalam proses koreksi, karena membutuhkan banyak waktu untuk mencocokkan hasil jawaban peserta didik yang berbeda-beda khusunya pada soal dengan tipe esai. Oleh karena itu dibutuhkan aplikasi yang digunakan untuk mengoreksi jawaban siswa secara otomatis yang diharapakan dapat membantu pengajar untuk mengoreksi jawaban dari soal esai dengan cepat dan mudah. Metode yang digunakan pada penelitian ini adalah metode pengembangan dengan model prototype sebagai metode pengembangan sistem dan metode Cosine Similarity dan Synonym Recognition. Data uji yang digunakan pada penelitian ini adalah 116 jawaban siswa SMA Alam AlGhifari. Hasil dari penelitian ini adalah sebuah sistem yang memanfaatkan metode Cosine Similarity dan Synonym Recognition dan telah dilakukan pengujian menggunakan uji akurasi RMSE dengan beberapa tahapan. Hasil dari pengujian RMSE untuk total siswa 20, 50, 100, 116 siswa pada jawaban nomor 1 dan 2 masing-masing mendapatkan nilai error 7.07, 8.00, 6.16, 8.94, 6.78, 8.61, 6.88, dan 8.57. Nilai tersebut cukup tinggi dikarenakan terdapat jawaban siswa yang tidak similar dengan kunci jawaban namun pada nilai actual mendapat nilai yang bagus, terdapat jawaban siswa yang salah ketik, dan terdapat proses yang menyebabkan beberapa term atau kata yang hilang, karena term tersebut termasuk di dalam daftar stopword pada proses filtering.
\end{abstract}

Keyword : Cosine Similarity, Synonym Recognition, Text Mining, Ujian Esai, Penalaian Otomatis

\section{PENDAHULUAN}

\subsection{Latar Belakang}

Ujian adalah salah satu alat penialaian dalam proses belajar mengajar yang dilaksanakan secara menyeluruh untuk menentukan kualitas pembelajaran dan merupakan suatu alat ukur untuk mengukur perfoma peserta didik. Namun disisi lain ujian merupakan suatu pekerjaan rumah dan kesibukan tambahan yang harus dilakukan oleh pengajar terutama dalam proses koreksi.

Jawaban dengan tipe esai memberikan beragam kemungkinan jawaban, tergantung pemahaman masing-masing siswa. Hasil jawaban tipe esai bukan hanya benar atau salah tetapi juga bisa mengahasilkan nilai hampir benar. Sehingga skor nilai untuk jawaban essay bisa beragam [1].

Soal dengan tipe esai tersebut membutuhkan banyak waktu untuk mencocokkan hasil jawaban peserta didik yang berbeda-beda dengan jawaban yang benar, pengajar harus membaca satu persatu jawaban peserta didik dan terkadang terdapat tulisan peserta didik yang sulit dibaca. Salah satu kekurangan pada jawaban dengan jenis essay yaitu sulitnya menilai jawaban dan membutuhkan banyak waktu untuk mengoreksi. Pengajar juga memiliki kendala sendiri-sendiri dalam proses koreksi jawaban, terkadang koreksi harus dibawa pulang oleh pengajar, sedangkan dirumah para pengajar juga memiliki tanggung jawab yang tidak bisa ditinggalkan [2]. Pengajar bukan hanya berkewajiban mengajar dan mengoreksi jawaban siswa, namun juga memiliki kewajiban administrasi lainnya seperti menyusun Rencana Pelaksanaan
Pembelajaran, menyusun silabus, program tahunan dan lain sebagainya, dimana kewajiban tersebut membutuhkan waktu yang tidak sedikit.

Berdasarkan masalah tersebut penelitian ini mengusulkan sebuah aplikasi penilaian jawaban esai secara otomatis. Penilaian akan dilakukan secara otomatis dengan mengenali kata yang mengandung sinonim menggunakan metode synonym recognition dan menghitung nilai kedekatan teks antara jawaban siswa dengan kunci jawaban menggunakan metode cosine similarity. Hasil dari sistem ini berupa nilai kemiripan antara kunci jawaban yang dimiliki guru dengan jawaban siswa.

Oleh karena itu peneliti mencoba menerapkan judul "Aplikasi Penilaian Jawaban Esai Otomatis Menggunakan Metode Synonym Recognition dan Cosine Similarity Berbasis Web".

\subsection{Pembatasan Masalah}

Batasan masalah digunakan untuk menghindari adanya penyimpangan atau pelebaran topik masalah agar penelitian lebih terarah, oleh karena itu penulis memberikan batasan masalah sebagai berikut:

1. Penelitian ini hanya berfokus pada perancangan sistem penilaian jawaban esai otomatis.

2. Penelitian ini dilakukan di SMA Alam AlGhifari.

3. Mata pelajaran yang digunakan dalam uji coba penelitian adalah Bahasa Indonesia dengan total siswa 116 siswa. 
4. Aplikasi penilaian jawaban esai otomatis yang dibuat untuk sistem berbasis website.

5. Penilaian jawaban esai otomatis bisa digunakan untuk jawaban berbasis teks Bahasa Indonesia.

6. Output yang dihasilkan dari sistem ini yaitu nilai kemiripan dari metode cosine similarity dan nilai pengujian dari metode yang digunakan.

7. Pengujian yang dilakukan menggunakan pengujian Root Mean Square Error (RMSE).

\section{TINJAUAN PUSTAKA}

\subsection{Penilaian}

Menurut Permendikbud No.23 Tahun 2016, penilaian merupakan sebuah proses pengumpulan dan pengolahan informasi untuk mengukur pencapaian hasil belajar peserta didik. Penilaian adalah kata lain istilah assessment bukan merupakan sebuah evaluasi karena sering disalah artikan.

\subsection{Synonym Recognition}

Synonym Recognition berfungsi untuk mengenali kata dengan penulisan berbeda tetapi memiliki makna yang sama. Selama pengenalan kata, isi dokumen dibandingkan dengan tesaurus dalam database. Jika kata yang dicari tidak tersedia dalam tesaurus, proses pengenalan sinonim tidak dilakukan. Seluruh isi dokumen dipindai dan dibandingkan dengan kata-kata dalam tesaurus, kemudian dimodifikasi berdasarkan isi tesaurus.

\subsection{Cosine Similariy}

Cosine similarity digunakan dalam ruang positif, dimana hasilnya dibatasi antara nilai 0 dan 1 , jika nilainya 0 maka dokumen tersebut dikatakan mirip jika hasilnya 1 maka nilai tersebut dikatakan tidak mirip [3]. Cosine similarity bisa hanya dihitung sebagai nilai rentang cosine similarity dari 0 hingga 1 sebagai sudut antara vektor dapat berada di antara 0 sampai 90 derajat, semakin mirip dokumennya maka semakin kecil sudutnya di antara vector [4].

\subsection{Kajian Penelitian}

Salim (2017) pada penelitiannya yang berjudul "Pengembangan Aplikasi Penilaiain Ujian Essay Berbasis Online Menggunakan Algoritma Nazief Adriani dengan Metode Cosine Similarity", yang menjadi masalah pada soal berbentuk esai adalah siswa harus menjawab dengan bentuk kalimat. Dengan begitu jawaban dapat bervariasi berdasarkan pemikiran siswa. Salah satu kelemahan jawaban dalam bentuk esai adalah sulitnya menilai jawaban yang membutuhkan banyak waktu. Penelitian yang dilakukan Salim diperoleh bahwa tidak terdapat beda yang besar antara mean nilai siswa koreksi otomatis metode cosine similarity dengan koreksi manual yaitu sebesar 1,6 dengan mean koreksi otomatis sebagai variabel lebih besar.
Sejalan dengan penelitian yang dilakukan oleh Salim (2017), penelitian yang dilakukan oleh Fataruba (2018) menjelaskan bahwa pengajar memerlukan waktu yang banyak untuk memeriksa jawaban essay, semakin banyak jumlah ujian dan banyaknya jumlah pelajar yang mengikuti ujian, maka semakin banyak jumlah ujian yang dikoreksi oleh pengajar. Penelitian tersebut menggunakan metode Cosine Similarity dan mendapatkan hasil akurasi sistem dalam memberikan nilai siswa mencapai $80 \%$ berdasarkan data yang dihitung menggunakan confision matrix.

\section{METODE PENELITIAN}

3.1. Metode Pengembangan Perangkat Lunak

Metode penelitian ini menggunakan metode pengembangan dengan model prototype. Metode prototyping pada penelitian ini bertujuan untuk mendapatkan gambaran tentang aplikasi yang dibuat berdasarkan perancangan aplikasi, hasil perancangan aplikasi tersebut berupa prototype yang kemudian akan dievaluasi oleh pengguna. Hasil dari evaluasi pengguna menjadi acuan untuk pembuatan aplikasi yang digunakan sebagai produk akhir.

\subsection{Teknik Pengumpulan Data}

Teknik pengumpulan data pada penilitian ini adalah dengan melakukan wawancara dan observasi bertempat di SMA Alam Al-Ghifari yang beralamat di Jl. Sumba GG III, Karangtengah, Kec. Sananwetan, Kota Blitar. Peneliti melakukan wawancara dengan salah satu guru SMA Alam AlGhifari. Pengumpulan data dengan Teknik wawancara dan observersi digunakan untuk menggali data dan informasi serta mengamati subyek yang diteliti.

\subsection{Membangun Prototype}

Membangun prototyping dengan membuat perancangan sementara yang berfokus kepada pengguna dengan menggunakan diagram context, flowchart sistem, Data Flow Diagram, Entity Relational Diagram, struktur database dan desain tampilan. Tahapan membangung prototype pada penelitian ini sebagai berikut:

\subsection{Flowchart Sistem}

Berdasarkan hasil Analisa kebutuhan, diperlukan perancangan sistem penilaian jawaban esai otomatis sehingga dapat membantu pengajar/guru dalam menilai jawaban esai secara otomatis. Berikut flowchart sistem yang digunakan peneliti dalam sistem yang dibangun ditampilkan pada gambar 1: 


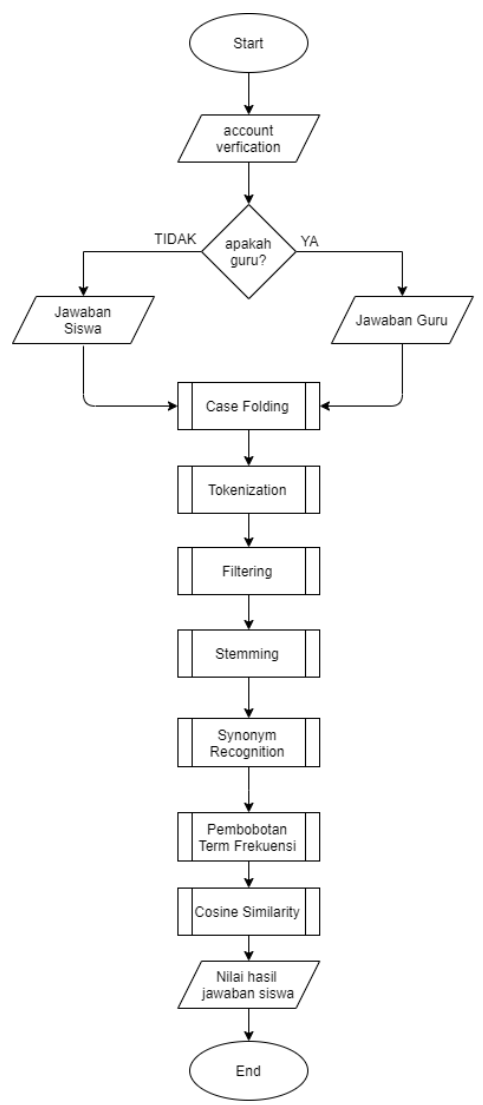

Gambar 1. Flowchart sistem

Langkah pertama pengguna melakukan account verification, kemudian sistem akan mengecek apakah pengguna adalah guru atau siswa. Jika pengguna adalah guru, selanjutnya pengguna melakukan input kunci jawaban, namun jika pengguna adalah murid maka pengguna melakukan input jawaban. Input yang dilakukan oleh guru maupun siswa selanjutnya dilakukan proses teks preprocessing, meliputi 4 tahap yaitu: case folding, tokenization, filtering, dan stemming. Hasil dari teks preprocessing tersebut masuk ke tahap synonym recognition, input dari pengguna akan di scan kata per kata untuk dicek ke dalam database sinonim, jika kata terdapat pada database sinonim maka kata tersebut akan diganti ke dalam bentuk sinonim, namun jika tidak ada maka kata tersebut tidak diganti. Selanjutnya masuk ke tahap perhitungan kemiripan dengan metode cosine similarity. Jawaban siswa dan kunci jawaban guru hasil synonym recognition akan di hitung tingkat similaritasnya menggunakan rumus 1 . Hasil dari tingkat similaritas kemudian di tampilkan kepada pengguna.

\subsection{Flowchart Synonym Recognition}

Untuk menggambarkan proses dari metode synonym recognition, maka penulis menambahkan flowchart Synonym Recognition seperti gambar 2:

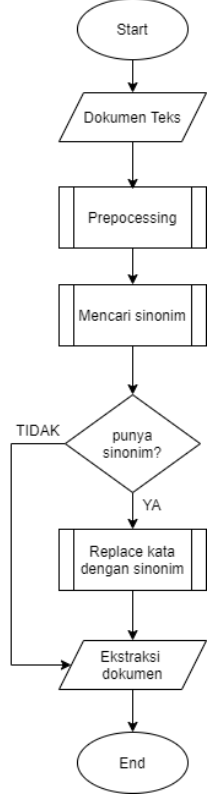

Gambar 2. Flowchart synonym recognition

Dimulai dari pengguna melakukan input dokumen berupa jawaban untuk siswa, dan kunci jawaban untuk pengguna guru. Dokumen tersebut selanjutnya masuk ke dalam tahap teks preprocessing tahap ini memiliki 4 tahap pemrosesan yaitu, case folding, tokenization, filtering dan stemming. Hasil dari teks preprocessing selanjutnya dimasukkan ke dalam metode synonym recognition. Sistem akan scan kata pada dokumen untuk dicari sinonimnya di dalam database sinonim. Jika kata memiliki sinonim di dalam database, maka kata tersebut di ubah ke dalam bentuk sinonimnya, namun jika tidak ada maka kata tersebut tidak diganti. Selanjutnya hasil synonym recognition di tampilkan.

\subsection{Flowchart Cosine Similarity}

Untuk menggambarkan proses perhitungan menggunakan metode cosine similarity, penulis menambahkan flowchart Cosine Similarity seperti pada gambar 3: 


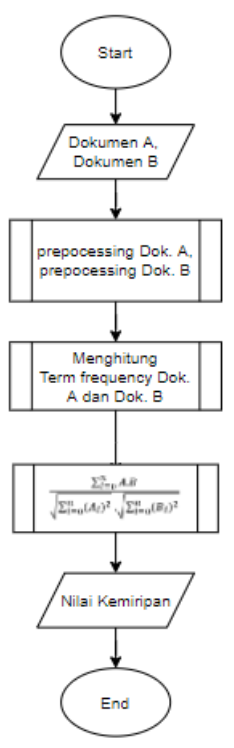

Gambar 3. Flowchart Cosine Similarity

Langkah pertama pada flowchart diatas adalah pengguna melakukan input dokumen berupa kunci jawaban untuk pengguna guru atau jawaban untuk pengguna siswa. Selanjutnya masuk ke dalam proses teks preprocessing, hasil dari teks preprocessing kemudian dilakukan perhitungan term frequency dari kunci jawaban dan jawaban siswa. Hasil term frequency berupa vektor dari dokumen, vektor tersebut kemudian dimasukkan ke dalam rumus perhitungan cosine similarity. Setelah dilakukan perhitungan maka akan ditampilkan nilai kemiripan antara kunci jawaban dan jawaban siswa.

\subsection{Evaluasi Prototype}

Tahap ini dilakukan pengguna untuk mengetahui apakah prototype yang memenuhi kebutuhan pengguna. Jika sesuai, maka dilanjutkan pada langkah keempat. Jika tidak, maka prototype diperbaiki dengan mengulang tahap 1, 2, dan 3 . Tahap ini peneliti melakukan evaluasi prototype pada kegiatan seminar proposal, dan hasil dari evaluasi prototype tidak ditemukan kekurangan kebutuhan sistem pada tahap prototype, maka dari hasil tersebut peneliti melakukan tahap selanjutnya yaitu pengkodean sistem.

\subsection{Pengkodean Sistem}

Dalam tahap ini prototype yang disetujui dilakukan pembuatan sistem aplikasi berbasis website dengan bahasa pemrograman php dan database MySQL. Tahapan-tahapan pengkodean sistem adalah sebagai berikut:

1. Tahap Preprocessing

Proses preprocessing adalah proses tahap awal untuk melakukan pemrosesan teks sebelum masuk kedalam algoritma yang digunakan, dengan memasukkan kunci jawaban dan jawaban siswa.
Table 1. Kunci dan jawaban siswa

\begin{tabular}{|l|l|}
\hline \multicolumn{1}{|c|}{ Kunci jawaban } & \multicolumn{1}{c|}{ Jawaban siswa } \\
\hline Wawancara adalah tanya & Wawancara ialah \\
jawab antara & tanya jawab antara \\
pewawancara dengan & pewanwancara \\
orang yang & dengan narasumber \\
diwawancarai/narasumber & untuk memperoleh \\
dengan tujuan untuk & data tertentu \\
memperoleh data untuk & \\
keperluan tertentu & \\
\hline
\end{tabular}

Kunci dan jawaban siswa diatas kemudian masuk ke dalam tahap preprocessing, yaitu case folding, tokenization, filtering, dan stemming.

Table 2. Hasil case folding

\begin{tabular}{|l|l|}
\hline \multicolumn{1}{|c|}{ Kunci jawaban } & \multicolumn{1}{|c|}{ Jawaban siswa } \\
\hline wawancara adalah tanya & wawancara ialah \\
jawab antara & tanya jawab antara \\
pewawancara dengan & pewanwancara \\
orang yang & dengan narasumber \\
diwawancarai/narasumber & untuk memperoleh \\
dengan tujuan untuk & data tertentu \\
memperoleh data untuk & \\
keperluan tertentu & \\
\hline
\end{tabular}

Table 3. Hasil tokenization

\begin{tabular}{|c|c|}
\hline Kunci jawaban & Jawaban siswa \\
\hline wawancara & wawancara \\
\hline adalah & ialah \\
\hline tanya & tanya \\
\hline jawab & jawab \\
\hline antara & pewawancara \\
\hline pewawancara & dengan \\
\hline dengan & narasumber \\
\hline orang & memperoleh \\
\hline yang & data \\
\hline diwawancarai & tertentu \\
\hline narasumber & \\
\hline dengan & \\
\hline tujuan & \\
\hline untuk & \\
\hline memperoleh & \\
\hline data & \\
\hline untuk & \\
\hline keperluan & \\
\hline tertentu & \\
\hline
\end{tabular}

Table 4. Hasil Filtering

\begin{tabular}{|c|c|}
\hline Kunci jawaban & Jawaban siswa \\
\hline wawancara & wawancara \\
\hline pewawancara & pewawancara \\
\hline orang & narasumber \\
\hline diwawancarai & memperoleh \\
\hline narasumber & data \\
\hline tujuan & \\
\hline memperoleh & \\
\hline data & \\
\hline keperluan & \\
\hline
\end{tabular}


Table 5. Hasil stemming

\begin{tabular}{|c|c|}
\hline Kunci jawaban & Jawaban siswa \\
\hline wawancara & wawancara \\
\hline wawancara & wawancara \\
\hline orang & narasumber \\
\hline wawancara & oleh \\
\hline narasumber & data \\
\hline tuju & \\
\hline oleh & \\
\hline data & \\
\hline
\end{tabular}

2. Tahap Synonym Recognition

Tahap selanjutnya adalah mencari sinonim dari masing-masing term atau kata di dalam database. Jika term memiliki sinonim di dalam database maka term tersebut diubah ke dalam sinonimnya, namun jika tidak memiliki sinonimnya maka term tidak diubah. Hasil synonym recognition sebagai berikut:

Table 6. Hasil synonym recognition

\begin{tabular}{|c|c|}
\hline Kunci jawaban & Jawaban siswa \\
\hline wawancara & wawancara \\
\hline wawancara & wawancara \\
\hline orang & informan \\
\hline wawancara & oleh \\
\hline informan & informasi \\
\hline tuju & \\
\hline oleh & \\
\hline informasi & \\
\hline perlu & \\
\hline
\end{tabular}

\section{Tahap Cosine Similarity}

Jika proses preprocessing dan synonym recognition selesai maka tahap selanjutnya adalah mencari nilai similaritas dari kunci jawaban dan jawaban menggunakan metode cosine similarity. Sebelum menghitung cosine similarity masingmasing dokumen di cari term frekuensi.

Table 7. Hasil term frequency

\begin{tabular}{|c|c|c|}
\hline Term & $\begin{array}{c}\text { Term } \\
\text { dokumen } \\
\text { kunci } \\
\text { jawaban / } \\
\text { term A }\end{array}$ & $\begin{array}{c}\text { Term dokumen } \\
\text { jawaban siswa / } \\
\text { term B }\end{array}$ \\
\hline wawancara & 3 & 2 \\
\hline orang & 1 & 0 \\
\hline narasumber & 1 & 1 \\
\hline tuju & 1 & 0 \\
\hline oleh & 1 & 1 \\
\hline data & 1 & 1 \\
\hline perlu & 1 & 0 \\
\hline
\end{tabular}

Hasil dari term frekuensi diatas dimasukkan ke dalam rumus cosine similarity.

$$
\operatorname{Similariy}(A, B)=\frac{\sum_{i=0}^{n} A \cdot B}{\sqrt{\sum_{i=0}^{n}\left(A_{i}\right)^{2}} \cdot \sqrt{\sum_{i=0}^{n}\left(B_{i}\right)^{2}}}
$$

$\sum_{i=0}^{n} A \cdot B=6+0+1+0+1+1+0=9$

$\sum_{i=0}^{n}\left(A_{i}\right)^{2}=9+1+1+1+1+1+1=15$

$\sum_{i=0}^{n}\left(B_{i}\right)^{2}=4+0+1+0+1+1+0=7$

$=\frac{9}{\sqrt{15} \cdot \sqrt{7}}$

$=0.88$

Berdasarkan perhitungan diatas hasil cosine similarity adalah 0.88

\subsection{Menguji Sistem}

Sistem yang sudah menjadi suatu perangkat lunak yang siap digunakan, selanjutnya sistem dilakukan pengujian dahulu sebelum digunakan. Pengujian ini dilakukan dengan uji akurasi Root Mean Squared Error. Pengujian ini dilakukan beberapa tahap untuk memastikan sistem memiliki nilai error yang minimum.

\subsection{Evaluasi Sistem}

Tahap evaluasi sistem dilalukan untuk mengevaluasi apakah sistem yang telah selesai dibuat dan diuji sesuai dengan yang dibutuhkan. Jika sistem sudah sesuai dengan kebutuhan, maka dilakukan langkah selanjutnya yaitu penggunaan sistem, jika sistem belum sesuai kebutuhan maka mengulangi langkah pengkodean dan menguji sistem.

\subsection{Penggunaan Sistem}

Tahap penggunaan sistem adalah tahap terakhir dari pengembangan model prototype. Tahap ini prototype yang selesai diuji, dan dievaluasi siap untuk digunakan untuk memenuhi kebutuhan permasalahan pengguna

\section{HASIL DAN PEMBAHASAN}

\subsection{Paparan Data}

Peneliti melakukan penelitian di SMA Alam Al-Ghifari Kota Blitar dengan metode wawancara dan observasi. Hasil wawancara yang dilakukan oleh peneliti bisa disimpulkan bahwa guru memiliki kendala pada proses koreksi jawaban siswa. Kendala yang dialami guru yaitu proses koreksi yang membutuhkan waktu koreksi yang cukup lama, karena proses koreksi jawaban yang dilakukan oleh guru masih secara manual.

\subsection{Implementasi Sistem}

Implementasi sistem merupakan tahapan dimana sistem menjadi aplikasi berbasis website sesuai dengan desain perancangan yang telah dijelaskan pada bab sebelumnya.

\subsection{Halaman Ujian Siswa}

Gambar 4 merupakan halaman ujian siswa yang berfungsi sebagai lembar pengerjaan siswa terhadap soal yang diberikan. Halaman ini 
mengimplementasikan proses text mining ketika siswa melakukan simpan data jawaban.

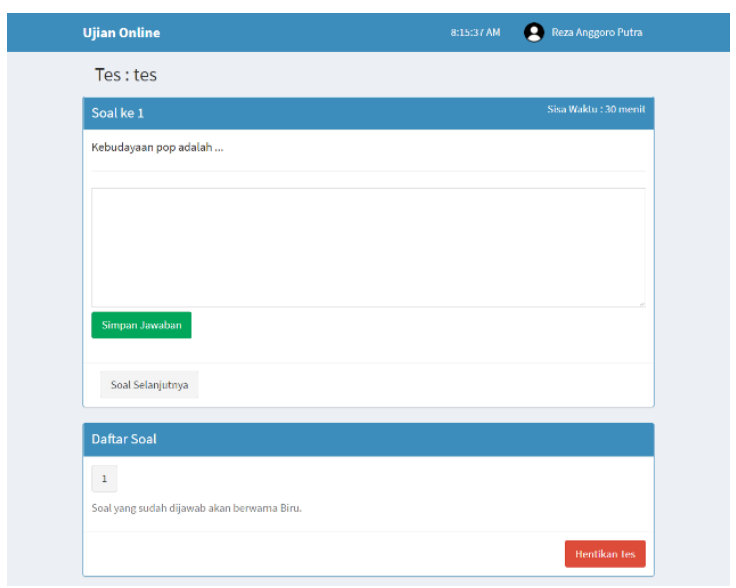

Gambar 4. Tampilan halaman ujian siswa

\subsection{Halaman Tambah Soal}

Halaman tambah soal berfungsi sebagai menambahkan soal-soal yang di sajikan ke dalam tes, Halaman ini hanya dapat di akses oleh level guru dan jenis soal yang ditambahkan adalah jenis soal esai. Saat guru menambah soal dilakukan proses text mining, hasil dari text mining tersebut disimpan ke dalaman database.

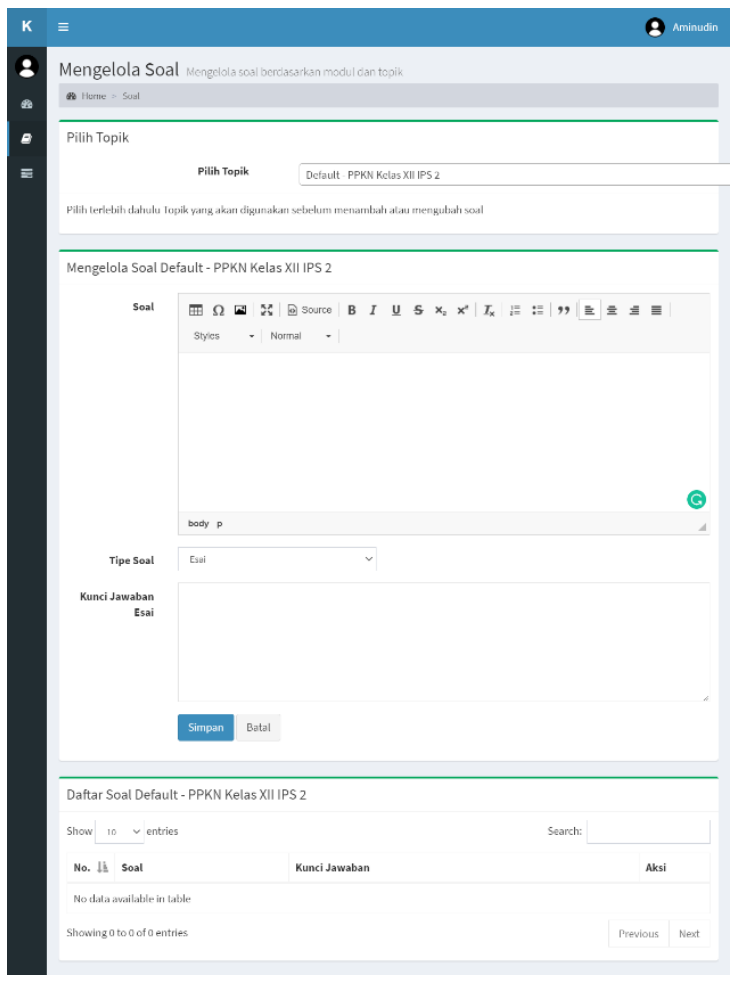

Gambar 5. Tampilan halaman tambah soal

\subsection{Halaman Evaluasi Tes}

Halaman evaluasi tes berfungsi sebagai tempat untuk koreksi otomatis yang dilakukan oleh guru, pada halaman ini proses algoritma synonym recognition dan cosine similarity digunakan untuk menilai jawaban esai secara otomatis. Jawaban siswa yang tampil pada halaman ini adalah siswa yang sudah menyelesaikan tes secara keseluruhan.

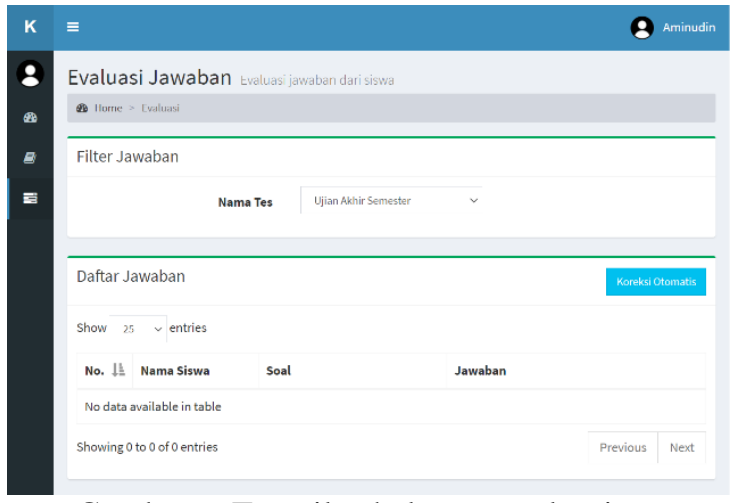

Gambar 6. Tampilan halaman evaluasi tes

\subsection{Halaman Hasil Tes}

Dari Gambar 7, jika siswa sudah menyelesaikan tes maka akan tampil di halaman hasil tes. Guru dapat mem-filter data yang tampil pada table berdasarkan nama tes, kelas, waktu, bahkan siswa yang sudah megerjakan ataupun belum mengerjakan.

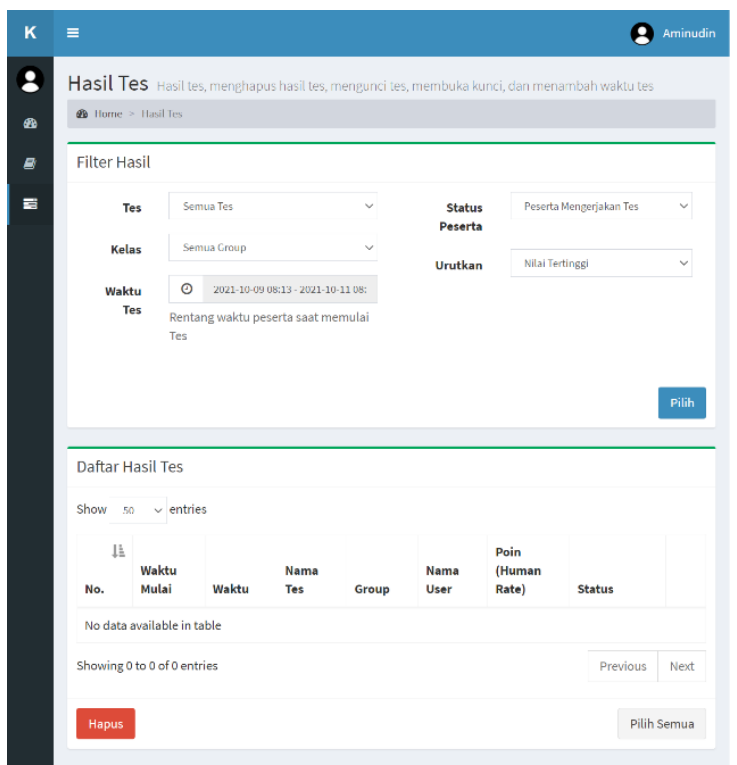

Gambar 7. Tampilan halaman hasil tes

\subsection{Pengujian RMSE}

Pengujian diperlukan untuk menvalidasi apakah sistem yang telah dirancang telah sesuai dengan yang diharapkan. Pada penelitian ini peneliti melakukan pengujian dengan beberapa tahapan dengan jumlah data berbeda, yaitu 20 data, 50 data, 100 data, dan 116 data menggunakan uji Root Mean Squared Error. Hasil dari perolehan nilai eror pada jumlah siswa 20 pada jawaban nomor 1 mendapatkan nilai error 7.07, sedangkan pada jawaban nomor 2 mendapatkan nilai error 8.00. Begitu juga untuk jumlah siswa 50 mendapatkan nilai error pada jawaban nomor 1 dan nomor 2 
masing-masing 6.16 dan 8.94. Sedangkan untuk jumlah siswa 100 dan 116 pada jawaban nomor 1 dan nomor 2 masing-masing mendapatkan nilai error $6.78,8.61,6.88$, dan 8.57. Hasil perolehan nilai error tersebut bisa dilihat pada tabel dibawah.

Table 8. Hasil RMSE

\begin{tabular}{|c|c|c|}
\hline \multirow{2}{*}{$\begin{array}{c}\text { Jumlah } \\
\text { siswa }\end{array}$} & \multicolumn{2}{|c|}{ Hasil RMSE (nilai) } \\
\cline { 2 - 3 } & $\begin{array}{c}\text { Jawaban } \\
\text { nomor 1 }\end{array}$ & $\begin{array}{c}\text { Jawaban } \\
\text { nomor 2 }\end{array}$ \\
\hline 20 & 7.07 & 8.00 \\
\hline 50 & 6.16 & 8.94 \\
\hline 100 & 6.78 & 8.61 \\
\hline 116 & 6.88 & 8.57 \\
\hline
\end{tabular}

Dari beberapa tahap pengujian menggunakan RMSE dengan data yang berbeda, dapat disimpulkan bahwa pengujian terdapat nilai RMSE yang cukup tinggi dikarenakan beberapa hal:

1. Terdapat jawaban siswa yang tidak similar dengan kunci jawaban namun pada nilai aktual yang diberikan oleh guru mendapatkan nilai yang sempurna, begitu juga sebaliknya

2. Terdapat kata pada jawaban siswa yang salah ketik, yang mengakibatkan nilai similaritasnya berkurang, padahal secara arti kata jawaban tersebut similar dengan kunci jawaban

3. Terdapat proses yang menyebabkan beberapa term atau kata yang hilang, karena term tersebut termasuk di dalam daftar stopword pada proses filtering.

\section{KESIMPULAN DAN SARAN}

\subsection{Kesimpulan}

Hasil penelitian yang telah dilakukan peneliti dapat disimpulkan sebagai berikut:

1. Perancangan aplikasi sistem penilaian jawaban esai otomatis menggunakan metode cosine similarity dan synonym recognition dilakukan beberapa tahap yakni membuat flowchart sistem, membuat DFD dan ERD, membuat rancangan database, kemudian membuat aplikasi itu sendiri.

2. Pengujian aplikasi sistem penilaian jawaban esai otomatis menggunakan uji akurasi Root Mean Squared Error (RMSE). Pengujian dilakukan beberapa tahapan dengan jumlah data uji yang berbeda. Terdapat hasil uji akurasi yang memiliki nilai error yang cukup tinggi dikarenakan sebagai berikut:

1) Jawaban siswa yang diuji memiliki tingkat similaritas yang rendah, namun pada nilai aktual memiliki nilai yang tinggi

2) Jawaban siswa mengandung kata yang salah dalam pengetikan, sehingga mengakibatkan nilai similaritasnya rendah, padahal kata tersebut memiliki arti yang sama dengan kata yang terdapat pada kunci jawaban.

3) Kata di dalam jawaban masuk ke dalam stopword yang mengakibatkan kata tersebut hilang pada proses filtering.

\subsection{Saran}

Saran yang diberikan dari peneliti untuk penelitian selanjutnya sebagai berikut:

1. Penulis berharap untuk penelitian selanjutnya bisa menambahkan tingkat similaritas antara dua buah teks dengan cara mencari kesamaan antar term berdasarkan jenis kata.

2. Diharapkan penelitian selanjutnya dapat dibuat aplikasi yang lebih dinamis untuk beberapa mata pelajaran atau beberapa bahasa.

3. Diharapkan untuk meningkatkan pengujian akurasi terhadap metode yang digunakan.

\section{DAFTAR PUSTAKA}

[1] A. Bastian dan H. Sujadi, "Implementasi dan Pengujian Aplikasi Penilaian Ujian Essay," Jurnal J-Ensitec, p. Vol. 05, 2018.

[2] N. N. E. Smrti, A. Saputra, Zulfachmi dan R. A. Setiawan, "Aplikasi Penilaian Otomatis Jawaban Soal Essay dengan Menggunakan Metode K-Nearest Neighbors," dalam Prosiding - Seminar Nasional Peningkatan Mutu Perguruan Tinggi, Tanjung Benoa-Bali, 2019.

[3] F. Fataruba, "Penerapan Metode Cosine Similarity untuk Pengecekan Kemiripan Jawaban Ujian Siswa,” JATI, pp. 88-95, 2018.

[4] J. Zizka, F. Darena dan A. Svoboda, Text Mining Machine Learning Principle and Techniques, Taylor \& Francis Group, 2019.

[5] M. A. Salim, "Pengembangan Aplikasi Penilaian Ujian Essay Berbasis Online Menggunakan Algoritma Nazief Adriani dengan Metode Cosine Similarity," Jurnal ITEDU, p. Vol. 02, 2017. 